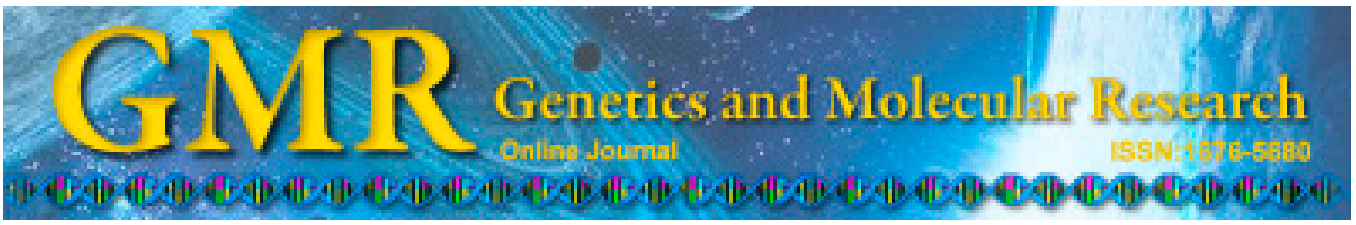

\title{
Streptomyces ansochromogenes Tur-10 produces a substance with antifungal bioactivity
}

\author{
N.M. Vasconcelos, J.M. Fontes, M.R.C.R. Lins, G.R.B. Bernardo, \\ J.M. Araújo and G.M.S. Lima \\ Laboratório de Coleção de Microrganismos, Departamento de Antibióticos, \\ Centro de Ciências Biológicas, Universidade Federal de Pernambuco, Recife, PE, \\ Brasil \\ Corresponding author: G.M.S. Lima \\ E-mail: gmslima@yahoo.com.br
}

Genet. Mol. Res. 14 (2): 5435-5444 (2015)

Received June 26, 2014

Accepted November 13, 2014

Published May 22, 2015

DOI http://dx.doi.org/10.4238/2015.May.22.13

\begin{abstract}
The increased incidence of fungal infections and the development of drug resistance have led to the search for microorganisms capable of producing bioactive metabolites with antifungal activity. Among these microorganisms, Streptomyces spp are distinguished mainly owing to their potential to secrete bioactive molecules. The aim of this study was to evaluate the production of secondary metabolites by Streptomyces sp TUR-10 against 12 fungal clinical isolates (yeast and filamentous fungi). In the preliminary screening, Streptomyces sp TUR-10 showed activity against $75 \%$ of the clinical isolates, and was selected for fermentation. In this assay, we tested three different media (MPE, M1, and ISP-4) for $96 \mathrm{~h}$ at $\mathrm{pH} 7.0$ and $30^{\circ} \mathrm{C}$ for the production of bioactive metabolites. Increased production of bioactive compounds was observed when using the MPE medium for $48 \mathrm{~h}$, with good activity against Candida pelliculosa. The minimum inhibitory concentration showed significant antifungal activity values ranging from 15.6 to 250 $\mu \mathrm{g} / \mathrm{mL}$. The actinobacterium was characterized by $16 S \mathrm{rRNA}$ analysis
\end{abstract}


and the pattern suggested that the isolate studied belonged to the species Streptomyces ansochromogenes. The biotechnological potential of this strain was also demonstrated by the detection of the nrps and $p k s$ genes. These results indicate the production of secondary metabolites of biotechnological interest by actinobacteria from the rhizosphere, suggesting great potential for further research.

Key words: Actinomycetes; Antifungal activity; Antimicrobial activity; pks gene; nrps gene; Streptomyces ansochromogenes

\section{INTRODUCTION}

The indiscriminate use of synthetic antifungals has increasingly promoted the emergence of pathogens with resistance profiles. Attention to the irrational use of drugs derives from the fact that, according to the World Health Organization (WHO, 2010), more than 50\% of all medicines are incorrectly prescribed, distributed, and sold; and more than $50 \%$ of patients use them incorrectly (Gaash, 2008).

Studies have been conducted that take into account the growing number of infections, both fungal and bacterial, in order to obtain new pharmacological compounds that are less toxic to human beings and that show effective activity against resistant microorganisms (Kitouni et al., 2005).

Among the filamentous and yeast-like fungi of clinical interest that cause mycosis, Cryptococcus, Candida albicans, Aspergillus, Tricophytum, Cladosporium, and Microsporum account for $90 \%$ of fungal infections in human beings, and are most commonly isolated in hospital environments. Their occurrence is often increased in patients with compromised immune functions caused by human immunodeficiency virus, chemotherapy treatments, and transplantations, or even those who undergo invasive procedures or use a broad-spectrum antimicrobial agent (Leiva et al., 2004).

A variety of natural products have been studied, a large part of which are secondary metabolites produced by microorganisms, and many have biotechnological applications. Among these microorganisms, the actinobacteria are a major source of bioactive metabolites with antimicrobial activity (Malviya et al., 2009).

The genus Streptomyces is noteworthy owing to its frequent occurrence in soil, and is widely known for its ability to produce different types of bioactive substances such as antibiotic agents. About $75 \%$ of natural antibiotic agents are produced by Streptomyces spp (Nikodinovic et al., 2003).

In studies previously carried out by our research group, we observed that Streptomyces sp TUR-10 has characteristics that are important for the antagonism of pathogenic microorganisms (Bernardo, 2012). Therefore, it was deemed appropriate to conduct this study in order to evaluate its antifungal activity against various clinical isolates.

\section{MATERIAL AND METHODS}

\section{Microorganisms}

Streptomyces sp TUR-10 was isolated from the rhizosphere of Terminalia fagifolia, which belongs to the Caatinga biome and is deposited at the Microorganism Culture Collection of Departamento de Antibióticos of Universidade Federal de Pernambuco (UFPEDA). 
The following fungi were supplied by the URM Collection at the Department of Mycology (DM/UFPE): Candida pelliculosa (URM 6281); Candida albicans (URM 6401); Candida guilliermondii (URM 6403); Candida parapsilosis (URM 6431); Candida glabrata (URM 6392); C. albicans (URM 6395); Epidermophyton floccosum (URM 3182); Fusarium solani (URM 5903); Trichophyton rubrum (URM 5908); Microsporum gypseum (URM 6199); Trichophyton mentagrophytes (URM 6272); and Aspergillus niger (URM 6642).

\section{Antifungal activity of Streptomyces sp TUR-10}

\section{Preliminary bioassay}

To evaluate the antifungal activity of Streptomyces sp TUR-10, we used the agar block assay (Ichikawa et al., 1971). For this, the actinobacteria were cultivated in ISP-4 medium (Shirling and Gottlieb, 1966) and arginine yeast agar (AYA) (Nonomura and Ohara, 1969) at $37^{\circ} \mathrm{C}$. After 5 days, $10-\mathrm{mm}$ agar blocks were placed on Sabouraud (SAB) plates containing yeast and filamentous fungi [Clinical Laboratory and Standards Institute (CLSI), 2008]. Plates were re-incubated at $30^{\circ} \pm 2^{\circ} \mathrm{C}$ and the inhibition zones were re-measured after $48 \mathrm{~h}$ for yeasts and after $120 \mathrm{~h}$ for filamentous fungi. The experiment was performed in triplicate.

\section{Secondary assay}

Streptomyces sp TUR-10 was cultivated in the media ISP-4 (Soluble starch $20 \mathrm{~g} / \mathrm{L}$, $\mathrm{K}_{2} \mathrm{HPO}_{4} 2 \mathrm{~g} / \mathrm{L}, \mathrm{MgSO}_{4} 7 \mathrm{H}_{2} \mathrm{O} 2 \mathrm{~g} / \mathrm{L}, \mathrm{NaCl} 2 \mathrm{~g} / \mathrm{L},\left(\mathrm{NH}_{4}\right)_{2} \mathrm{SO}_{4} 4 \mathrm{~g} / \mathrm{L}, \mathrm{CaCO}_{3} 4 \mathrm{~g} / \mathrm{L}$ ); M1 (glucose $10 \mathrm{~g} / \mathrm{L}$, soy powder $10 \mathrm{~g} / \mathrm{L}, \mathrm{NaCl} 5 \mathrm{~g} / \mathrm{L}, \mathrm{CaCo}_{3} 1 \mathrm{~g} / \mathrm{L}$ ); MPE (glucose $20 \mathrm{~g} / \mathrm{L}$, soy powder $20 \mathrm{~g} / \mathrm{L}$, $\mathrm{NaCl} 5 \mathrm{~g} / \mathrm{L}, \mathrm{CaCo}_{3} 2 \mathrm{~g} / \mathrm{L}$ ) (Kawamura et al., 1976), and stirred at $200 \mathrm{rpm}$ and $37^{\circ} \mathrm{C}$ for $48 \mathrm{~h}$. After this period, $10 \%(\mathrm{v} / \mathrm{v})$ was transferred to Erlenmeyer flasks containing $50 \mathrm{~mL}$ medium. Every $24 \mathrm{~h}$, a 1-mL aliquot was taken to evaluate the dry weight, antimicrobial activity, and $\mathrm{pH}$. For determining dry weight, samples were centrifuged and the tubes containing the cell mass were returned to the incubator for drying and weighing. For evaluating the antifungal activity of secondary metabolites, a disc diffusion test was performed. Fifty-microliter aliquots fermented liquid were placed on SAB plates containing yeast and filamentous fungi (CLSI, 2008). The plates were incubated at $30^{\circ} \mathrm{C}$ for $48-120 \mathrm{~h}$. The disc diffusion test was performed in triplicate and the results were determined through the arithmetic average of the inhibition zone diameters in millimeters (CLSI, 2008).

\section{Extraction of bioactive metabolites}

Streptomyces sp TUR-10 was cultivated in the MPE medium at $37^{\circ} \mathrm{C}$ for $48 \mathrm{~h}$ at 200 rpm. Extraction of metabolites from the cell mass and liquid was then performed. The cell mass was treated with acetone, ethanol, and pure methanol at $\mathrm{pH}$ 2.0, 7.0, and 9.0, and for the metabolic liquid we used ethyl acetate, chloroform, and pure petroleum ether at the same $\mathrm{pH}$ values mentioned above. The $\mathrm{pH}$ was then adjusted to 7.0 , and the antifungal activity was assessed using the disc diffusion test (Porto et al., 1996).

\section{Determination of minimum inhibitory concentration (MIC)}

The MIC of the extracts was determined using the macrodilution technique, according 
to the CLSI (2008) guidelines. The extracts were tested at concentrations ranging from 3.9 to $1000 \mu \mathrm{g} / \mathrm{mL}$. Amphotericin B concentrations were 7.8 to $1000 \mu \mathrm{g} / \mathrm{mL}$. The minimum fungicidal concentration was determined by a subculture in the assay of MIC in a SAB medium. Plates were incubated at $30^{\circ} \mathrm{C}$ from 48 to $120 \mathrm{~h}$ (Koneman et al., 2006).

\section{Identification of actinobacteria}

\section{Classical taxonomy}

For identifying micromorphology, Streptomyces sp TUR-10 was inoculated as a wide streak on the ISP-4 culture medium, coverslips were inserted at $45^{\circ}$ inclination on the streak to induce growth of aerial mycelia on the coverslip, and the culture medium was incubated at $37^{\circ} \mathrm{C}$ for 5-10 days. A coverslip was removed to observe the formation of the spores-sporophores chains under an optical microscope (Medilux, MDL-150-BAI) at 40X objective, according to the technique proposed by Shirling and Gottlieb (1966).

\section{Molecular taxonomy}

DNA extraction was performed on the culture grown in ISP-2 liquid medium for 16 $\mathrm{h}$ at $37^{\circ} \mathrm{C}$. Subsequently, the sample was centrifuged ( $3 \mathrm{~min}$ at $9168 \mathrm{~g}$ ) and DNA extraction was performed using the Wizard Genomic DNA Purification kit (Promega ${ }^{\circledR}$ ), according to manufacturer instructions. The DNA sequence was assessed by electrophoresis on agarose gel and the $16 S r R N A$ gene was amplified by polymerase chain reaction using universal oligonucleotides (Table 1).

Table 1. Oligonucleotides selected for amplifying $16 S r R N A$, pks, and $n r p s$.

\begin{tabular}{|c|c|c|c|c|}
\hline Gene & Oligonucleotides & Sequence 5'-3' & Fragment size (bp) & Reference \\
\hline $16 S$ rRNA & $\begin{array}{l}\text { fD1 } \\
\text { rD1 }\end{array}$ & $\begin{array}{l}\text { AGAGTTTGATCCTGGCTCAG } \\
\text { AAGGAGGTGATCCAGCC }\end{array}$ & 1500 & Weisburg et al. (1991) \\
\hline$p k s$ & $\begin{array}{l}\mathrm{ks} \alpha \\
\mathrm{ks} \beta\end{array}$ & $\begin{array}{l}\text { TSGRCTACRTCAACGGSCACGG } \\
\text { TACSAGTCSWTCGCCTGGTTC }\end{array}$ & 500 & Jenke-Kodama et al. (2005) \\
\hline nrps & $\begin{array}{l}\text { A3F } \\
\text { A7R }\end{array}$ & $\begin{array}{l}\text { GCSTACSYSATSTACACSTCSGG } \\
\text { SASGTCVCCSGTSCGGTAS }\end{array}$ & 700 & Jenke-Kodama et al. (2005) \\
\hline
\end{tabular}

The reaction mixture comprised $50 \mathrm{ng}$ DNA, 5 pmol of each oligonucleotide, $200 \mathrm{mM}$ dNTP, $1.5 \mathrm{mM} \mathrm{MgCl}_{2}, 1 \mathrm{X}$ buffer, and $1 \mathrm{U}$ Platinum Taq DNA polymerase (Invitrogen Life Technologies, Carlsbad, CA, USA), to a $25-\mu \mathrm{L}$ final volume. The reaction conditions were: 5 min of denaturation at $94^{\circ} \mathrm{C}$, followed by 25 cycles of $1 \mathrm{~min}$ at $94^{\circ} \mathrm{C}, 30 \mathrm{~s}$ at $52^{\circ} \mathrm{C}$, and $2 \mathrm{~min}$ at $72^{\circ} \mathrm{C}$; and a final extension of $10 \mathrm{~min}$ at $72^{\circ} \mathrm{C}$. The amplification product was analyzed by electrophoresis on $1.2 \%$ agarose gel, and the sample was sent for sequencing. The sample was sequenced by Macrogen (Seoul, Korea) and this sequence was compared with all sequences in GenBank using the BLAST software from the National Center for Biotechnology Information (www.ncbi.nlm.nih.gov). The sequence was aligned with the Clustal software and the phylogenetic tree was constructed using Mega 5.5. Topology was assessed by bootstrap analysis (1000 resamplings). 


\section{Assessing the actinobacteria potential by amplification of the non-ribosomal peptide synthetase (nrps) and polyketide synthase (pks) genes}

For amplifying sequences of the nrps and $p k s$ genes, we used the degenerate oligonucleotides described in Table 1. The reaction mixture comprised $50 \mathrm{ng}$ DNA, 5 pmol of each oligonucleotide, $200 \mathrm{mM}$ dNTP, $1.5 \mathrm{mM} \mathrm{MgCl}{ }_{2}$, $1 \mathrm{X}$ buffer, and 1 U Platinum Taq DNA polymerase (Invitrogen Life Technologies), to a $25-\mu \mathrm{L}$ final volume. The reaction conditions were: 5 min denaturation at $94^{\circ} \mathrm{C}$ followed by 30 cycles of $35 \mathrm{~s}$ at $94^{\circ} \mathrm{C}, 40 \mathrm{~s}$ at $55^{\circ} \mathrm{C}$, and $2 \mathrm{~min}$ at $72^{\circ} \mathrm{C}$. These cycles were followed by a final extension of $7 \mathrm{~min}$ at $72^{\circ} \mathrm{C}$. The amplification product was analyzed by electrophoresis on 1.2\% agarose gel (González et al., 2005).

\section{RESULTS}

The results of the preliminary bioassay showed good antimicrobial activity for $75 \%$ of the clinical isolates tested, with inhibition zones ranging from $20 \mathrm{~mm}$ for A. niger (URM 6642) and C. albicans (URM 6401) to $28 \mathrm{~mm}$ for C. guilliermondii (URM 6403). There was no significant activity for C. glabrata (URM 6392), T. rubrum (URM 5908), and F. solani (URM 5903) (Figure 1).

\begin{tabular}{|c|c|c|}
\hline C. parapsilosis URM 6431 & $\square$ A. niger URM 6642 & - C. albicans URM 6401 \\
\hline T. rubrum URM 5908 & $\llbracket T$. mentagrophytes $U R M 6272$ & DE. floccosum URM 3128 \\
\hline 目C. guilliermondis URM 6403 & C. peliculosa URM 6281 & घF. solani URM 5903 \\
\hline \& C. albicans URM 6395 & - C. glabata URM 6392 & 日M. gypseum URM 6199 \\
\hline
\end{tabular}

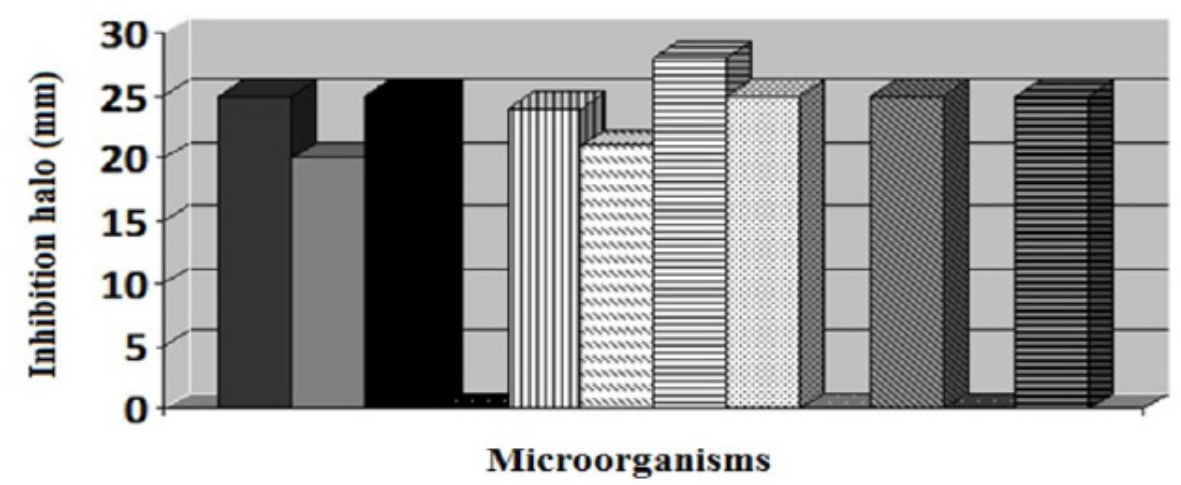

Figure 1. Antifungal activity of Streptomyces sp TUR-10 against pathogenic fungi detected by the preliminary bioassay in ISP-4 medium. Values of the inhibition zone are in millimeters.

The assessment of metabolite production was performed by means of the secondary assay using different culture media. Increased production of bioactive compound was observed when using the MPE medium for $48 \mathrm{~h}$ of fermentation. This medium was useful both for metabolite production and for microorganism growth (biomass of $0.23 \mathrm{~g}$ ) (Table 2).

Ethyl acetate and acetone extracts $(\mathrm{pH} 7)$ showed antimicrobial activity with zones of 20 and $22 \mathrm{~mm}$, respectively, for C. pelliculosa (URM 6281). 
MIC was defined as the minimum extract concentration that caused $100 \%$ inhibition of visible microorganism growth (turbidity). The ethyl acetate extract exhibited a MIC value of $15.6 \mu \mathrm{g} / \mathrm{mL}$ for C. guilliermondii (URM 6403), C. pelliculosa (URM 6281), and C. parapsilosis (URM 6431). Table 3 shows all the MIC values of the crude extracts tested on the various fungal isolates.

Table 2. Assessment of antifungal activity of Streptomyces sp TUR-10 (mm) during $48 \mathrm{~h}$ of fermentation in different culture media.

\begin{tabular}{lccc}
\hline TUR-10 & MPE & M1 & ISP-4 \\
\hline Clinical isolates & & & - \\
C. albicans URM 6401 & ++ & + & - \\
C. albicans URM 6395 & +++ & + & - \\
C. pelliculosa URM 6281 & + & + & - \\
C. guilliermondii URM 6403 & +++ & + & - \\
C. parapsilosis URM 6431 & +++ & + & - \\
E. floccosum URM 3182 & ++ & + & - \\
M. gypseum URM 6199 & ++ & + & - \\
T. mentagrophytes URM 6272 & ++ & + & + \\
A. niger URM 6642 & ++ & & + \\
\hline
\end{tabular}

Table 3. Values of minimum inhibitory concentration of the crude extracts and the positive control (amphotericin B) against fungi.

\begin{tabular}{|c|c|c|c|c|c|c|}
\hline \multirow[t]{2}{*}{ Clinical isolates } & \multicolumn{2}{|c|}{$\begin{array}{l}\text { MIC and MFC }(\mu \mathrm{g} / \mathrm{mL}) \\
\text { of ethyl acetate extract }\end{array}$} & \multicolumn{2}{|c|}{$\begin{array}{l}\text { MIC and MFC }(\mu \mathrm{g} / \mathrm{mL}) \\
\text { of acetone extract }\end{array}$} & \multicolumn{2}{|c|}{$\begin{array}{c}\text { MIC and MFC }(\mu \mathrm{g} / \mathrm{mL}) \\
\text { of amphotericin B }\end{array}$} \\
\hline & MIC & $\mathrm{MFC}$ & MIC & $\mathrm{MFC}$ & MIC & $\mathrm{MFC}$ \\
\hline C. albicans URM 6401 & 250.00 & 500.00 & 125.00 & 250.00 & 7.8 & 15.6 \\
\hline C. guilliermondii URM 6403 & 15.6 & 31.25 & 62.5 & 125.00 & 7.8 & 15.6 \\
\hline C. pelliculosa URM 6281 & 15.6 & 31.25 & 15.6 & 31.25 & 7.8 & 15.6 \\
\hline C. albicans URM 6395 & 31.25 & 62.5 & 125.00 & 250.00 & 7.8 & 15.6 \\
\hline C. parapsilosis URM 6431 & 15.6 & 31.25 & 15.6 & 31.25 & 7.8 & 15.6 \\
\hline E. floccosum URM 3182 & 25.00 & 250.00 & 250.00 & 500.00 & 15.6 & 31.25 \\
\hline A. niger URM 6642 & 31.25 & 62.5 & 125.00 & 250.00 & 15.6 & 31.25 \\
\hline M. gypseum URM 6199 & 31.25 & 62.5 & 125.00 & 250.00 & 15.6 & 31.25 \\
\hline T. mentagrophytes URM 6272 & 1000.00 & 1000.00 & 1000.00 & 1000.00 & 31.25 & 62.5 \\
\hline
\end{tabular}

Amphotericin B showed a MIC ranging from 7.8 to $31.25 \mu \mathrm{g} / \mathrm{mL}$. We determined amphotericin B resistance to be a concentration requirement of $\geq 4 \mu \mathrm{g} / \mathrm{mL}$ (CLSI, 2008).

The bacterial strain was identified as belonging to the genus Streptomyces, which has the morphological characteristic of forming chains with long spiral spores. In addition, we conducted a molecular analysis of the $16 \mathrm{~S} r R N A$ gene. A 1474-bp fragment was sequenced and it showed a similarity above $96 \%$ to Streptomyces ansochromogenes NBRC 13665 (Figure 2).

In this study, we also investigated the presence of the nrps and pks genes because they are involved in the biosynthesis of important antibiotic agents produced by actinobacteria, and Streptomyces sp TUR-10 amplifies both these genes. The amplification products were demonstrated by the presence of the 500-bp pks and 700-bp nrps genes. 


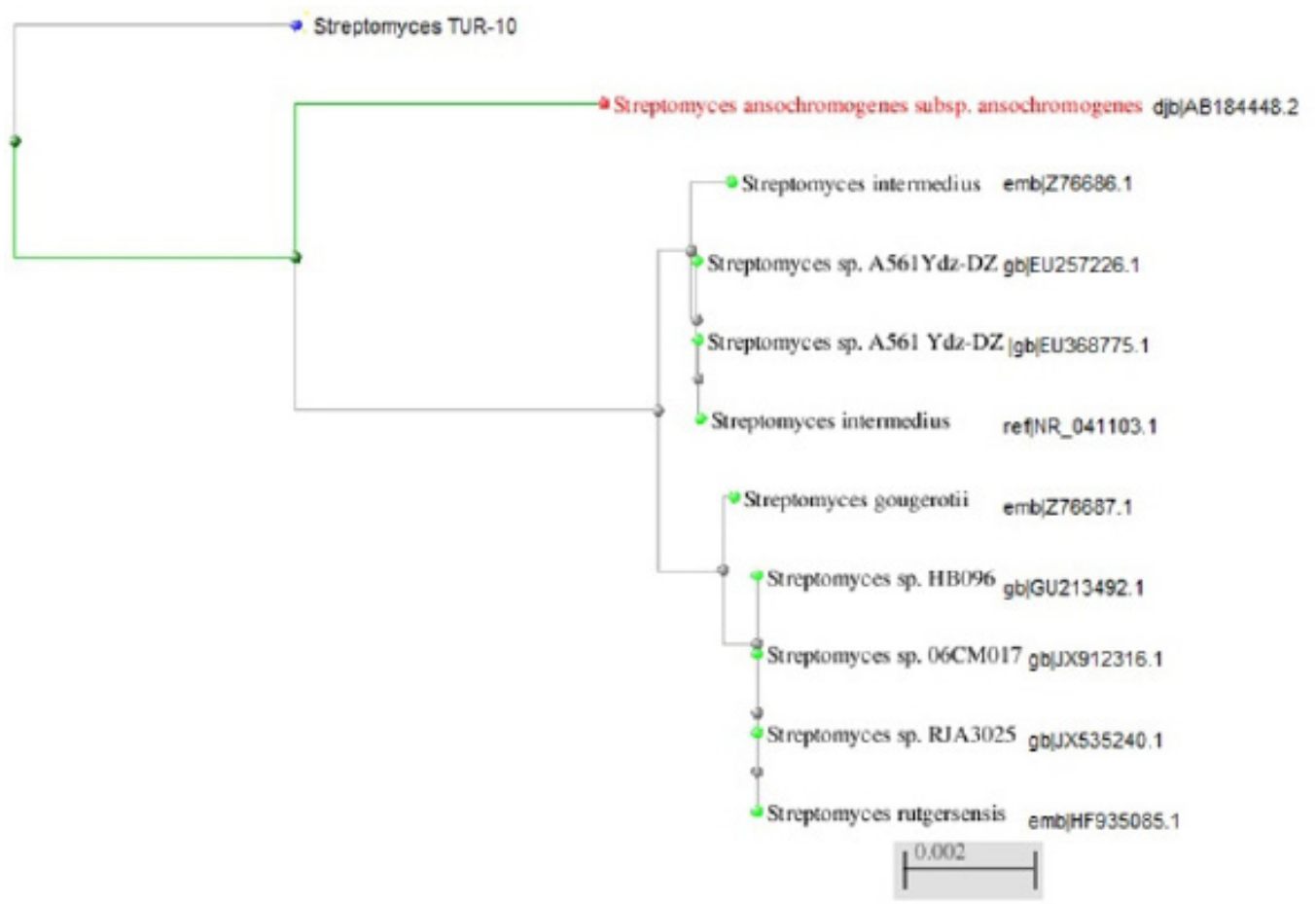

Figure 2. Neighbor-joining analysis based on the partial sequence of $16 \operatorname{Sr} D N A$, showing phylogenetic relationships between Streptomyces sp TUR-10 and other species of Streptomyces. Bar, sequence divergence of $0.2 \%$.

\section{DISCUSSION}

Soil represents a vast reservoir of microorganisms, a large part of which are found in the rhizosphere and have the ability to produce bioactive secondary metabolites. The production of antimicrobial agents is an important feature of the genus Streptomyces; they produce antiviral, antitumor, and immunosuppressive substances (Procópio et al., 2012).

Actinobacteria stand out owing to their broad activity in the face of various microorganisms, which means that they have great potential for applications in numerous areas of health and agriculture (Mukherjee and Sen, 2006; Zhao et al., 2011). In this study, the strain Streptomyces sp TUR-10, isolated from the rhizosphere of T. fagifolia (Caatinga biome), was identified by classical and molecular taxonomy as $S$. ansochromogenes TUR-10. The actinobacteria show significant antifungal activity. Reports in the literature show that $S$. ansochromogenes produces a number of antibiotic agents belonging to different chemical classes and with different structures (Chen et al., 2000; Tan et al., 2002; Liu et al., 2005). According to $\mathrm{Li}$ et al. (2012), S. ansochromogenes has strong antifungal activity that arises from chemical components such as nikkomycin $\mathrm{Z}$ and polyoxin, which are nucleoside peptide antibiotics that are strong competitive inhibitors of chitin synthesis.

It is known that fungal infections have a progressive nature and can present potentially severe stages in immunocompromised patients. According to Bassetti et al. (2011), several studies demonstrate a significant increase in candidiasis caused by fungi mainly involving 
the genus Candida, and particularly C. albicans. However, in the last 10 years, this etiologic profile has changed markedly, and increasing rates of candidiasis caused by other species such as C. tropicalis, C. parapsilosis, C. glabrata, and C. krusei have been reported worldwide. Thus, there is an urgent need to discover new drugs that are capable of controlling the growth of these microorganisms.

In our quality assessment of the assay on agar blocks, we found that ISP-4 medium was the best for determining antimicrobial activity. Several reports have shown that media containing starch are more suitable for antifungal activity than media containing glycerol and glucose (Nonoh et al., 2010; Shahat et al., 2011), which corroborates the fact that ISP-4, which contains starch, presented larger inhibition zones when compared with AYA medium, which comprises glycerol and glucose, in this study.

In this research, the MPE medium positively influenced the growth and production of secondary metabolites. Several studies have reported that the production of bioactive metabolites may be influenced by culture medium, time, and pH. Wang et al. (2010) observed increased antimicrobial activity in different strains of Streptomyces spp when $\mathrm{pH}$ reached a value of around 7.0. Bonfim (2008), working with endophytic Streptomyces, also found better activity in the face of yeasts for $48 \mathrm{~h}$ of fermentation with inhibition zones ranging from 20 to $23 \mathrm{~mm}$. The MPE medium has concentrations of carbon and nitrogen in its composition. The presence of these components may influence the production of secondary metabolites by Streptomyces spp and, therefore, result in larger inhibition zones (Ismet et al., 2004).

The solvents ethyl acetate and acetone were effective for extracting the metabolites that are active against the fungal isolates. Arasu et al. (2013) observed that the MIC of the ethyl acetate extract of Streptomyces sp AP-123 was $125 \mu \mathrm{g} / \mathrm{mL}$ when used against $A$. niger and E. floccosum. The results obtained in the current study demonstrate that $S$. ansochromogenes TUR-10 is effective against the fungal isolates tested and presents better results than those reported in the literature for Candida and A. niger, suggesting great fungicide potential.

Non-ribosomal peptides and polyketides represent important classes of compounds produced by bacteria, fungi, and plants. They include compounds with very diverse structures deriving from secondary metabolism, such as antibiotics, toxins, siderophores, and immunosuppressive agents. The production of these compounds is directly associated with the multifunctional enzymes PKS I, PKS II and NRPS (Hill, 2005).

The nrps and pks genes are involved in the synthesis of numerous biologically active compounds of great biotechnological importance. However, there are still few studies involving the search for these genes in actinobacteria. Xi et al. (2012) estimated that $27.5 \%$ of the isolates tested that belonged to the genus Streptomyces (34 isolates) showed antimicrobial activity, and it has been shown that the strains where both $p k s$ and $n r p s$ genes were identified produced a significantly higher number of secondary metabolites.

Zhong et al. (2013) demonstrated the assembly and features of secondary metabolite biosynthetic gene clusters with pks and nrps in S. ansochromogenes. In the current study, we provided evidence for the presence of both genes ( $r$ rps and pks) in the strain S. ansochromogenes TUR-10, suggesting that the production of the secondary metabolites might be performed by two metabolic routes. The peptide compounds produced by the non-ribosomal pathway have a broad spectrum of activity and great importance for the pharmaceutical industry. Some examples of this class of compounds are vancomycin, penicillin, and bleomycin (an antitumor substance) (Jenke-Kodama et al., 2005).

The data presented in this paper suggest that Streptomyces ansochromogenes TUR-10 
produces metabolites with antifungal activity, which are worthy of further research. New experiments should be conducted to investigate the active ingredients produced by this microorganism.

\section{REFERENCES}

Arasu MV, Duraipandiyan V and Ignacimuthu S (2013). Antibacterial and antifungal activities of polyketide metabolite from marine Streptomyces sp. AP-123 and its cytotoxic affect. Chemosphere 90: 479-487.

Bassetti M, Taramasso L, Nicco E, Molinari MP, et al. (2011). Epidemiology, species distribution, antifungal susceptibility and outcome of nosocomial candidemia in a tertiary care hospital in Italy. PLoS One 6: e24198.

Bernardo GRB (2012). Atividade antifúngica de actinobactérias da rizosfera de Terminalia fagifolia (bioma caatinga) ativas contra Candida spp. Undergraduate's thesis, Biomedicina, UFPE, Recife.

Bonfim SM (2008). Isolamento de metabólitos antifúngicos de Streptomyces sp. UFPEDA 3347, Endófito de Momordica charantia L. (Cucurbitaceae). Master's thesis, Programa de Pós-Graduação em Ciências Farmacêuticas, UFPE, Recife.

Chen W, Zeng H and Tan H (2000). Cloning, sequencing, and function of sanF: A gene involved in Nikkomycin biosynthesis of Streptomyces ansochromogenes. Curr. Microbiol. 41: 312-316.

Clinical Laboratory Standards Institute (CLSI) (2008). Reference method for broth dilution antifungal susceptibility testing of yeasts. Approved standard, 3rd edn. CLSI document M27-A3. Clinical Laboratory and Standards Institute, Wayne.

Gaash B (2008). Irrational use of antibiotics. Indian Journal for the Practising Doctor. Vol. 5, No.1 (2008-03 - 2008-04).

González I, Ayuso-Sacido A, Anderson A and Genilloud O (2005). Actinomycetes isolated from lichens: evaluation of their diversity and detection of biosynthetic gene sequences. FEMS Microbiol. Ecol. 54: 401-415.

Hill RA (2005). Marine natural products. Annu. Rep. Prog. Chem. 101: 124-136.

Ichikawa T, Date M, Ishikura T and Ozaki A (1971). Improvement of kasugamycin-producing strain by the agar piece method and the prototroph method. Folia Microbiol. 16: 218-224.

Ismet A, Vikineswary S, Paramaswari S, Wong WH, et al. (2004). Production and chemical characterization of antifungal metabolites from Micromonospora sp. M39 isolated from mangrove rhizosphere soil. World J. Microbiol. Biotechnol. 20: 523-528.

Jenke-Kodama H, Sandmann A, Müller R and Dittmann E (2005). Evolutionary implications of bacterial polyketid synthases. Mol. Biol. Evol. 22: 2027-2039.

Kawamura T, Tago K, Beppu T and Arima K (1976). Antiviral antibiotic S15-1. Taxonomy of the producing strain and study of conditions for production of the antibiotic. J. Antibiot. 29: 242-247.

Kitouni M, Boudemagh A, Oulmi L, Reghioua S, et al. (2005). Isolation of actinomycetes producing bioactive substances from water, soil and tree bark samples of the north-east of Algeria. J. Med. Mycol. 15: 45-51.

Koneman EW, Allen SD, Janda WM, Schreckenberger PC, et al. (2006). Koneman's Color Atlas and Textbook of Diagnostic Microbiology. 6th edn. Lippincott Williams \& Wilkins.

Leiva PS, Yáñez SM, Zaror CL, Rodríguez SH, et al. (2004). Actividad antimicrobiana de actinomycetes aislados desde ambientes acuáticos del sur de Chile. Rev Méd Chile 132: 151-159.

Li J, Li L, Feng C, Chen Y, et al. (2012). Novel polyoxins generated by heterologously expressing polyoxin biosynthetic gene cluster in the sanN inactivated mutant of Streptomyces ansochromogenes. Microb. Cell. Fact. 11: 135.

Liu G, Tian Y, Yang H and Tan H (2005). A pathway-specific transcriptional regulatory gene for nikkomycin biosynthesis in Streptomyces ansochromogenes that also influences colony development. Mol. Microbiol. 55:1855-1866.

Mukherjee G and Sen SK (2006). Purification, characterization, and antifungal activity of chitinase from Streptomyces venezuelae P10. Curr. Microbiol. 53: 265-269.

Malviya MK, Pandey A, Trivedi P, Gupta G, et al. (2009). Chitinolytic activity of cold tolerant antagonistic species of Streptomyces isolated from glacial sites of Indian himalaya. Curr. Microbiol. 59: 502-508.

Nikodinovic J, Barrow KD and Chuck JA (2003). High frequency transformation of the Amphotericin producing bacterium Streptomyces nodosus. J. Microbiol. Methods 55: 273-277.

Nonomura H and Ohara Y (1969). Distribution of soil actinomycetes. VI. A culture method effective for both preferential isolation and enumeration of Microbispora and Streptosporangium strains in soil. J. Ferment. Technol. 47: 463-469.

Nonoh JO, Lwande W, Masiga D, Herrmann R, et al. (2010). Isolation and characterization of Streptomyces species with antifungal activity from selected national parks in Kenya. Afr. J. Microbiol. Res. 4: 856-864.

Porto ALF, Campos-Takaki GM and Lima Filho JL (1996). Effects of culture conditions on protease production by Streptomyces clavuligerus growing soy bean flour medium. Appl. Biochem. Biotech. 60: 115-122.

Procópio RE, Silva IR, Martins MK, Azevedo JL, et al. (2012). Antibiotics produced by Streptomyces. Braz. J. Infect. Dis. 16: 466-471.

Shahat AS, Abouwarda A and El-Wafa WMA (2011). Production of anti-Candida albicans by Egyptian Streptomyces 
isolates. Int. J. Microbiol. Res. 2: 167-171.

Shirling EB and Gottlieb D (1966). Methods for characterization of Streptomyces species. Int. J. Syst. Evol. Microbiol. 16: 313-340.

Tan H, Tian Y, Yang H, Liu G, et al. (2002). A novel Streptomyces gene, samR, with different effects on differentiation of Streptomyces ansochromogenes and Streptomyces coelicolor. Arch. Microbiol. 177: 274-278.

Wang X, Huang L, Kang Z, Buchenauer H, et al. (2010). Optimization of the Fermentation Process of Actinomycete Strain Hhs.015T. J. Biomed. Biotechnol. 2010: 141876.

Weisburg WG, Barns SM, Pelletier DA and Lane DJ (1991). 16S ribosomal DNA amplification for phylogenetic study. J. Bacteriol. 173: 697-703.

WHO (World Health Organization) (2010). Medicine racional use of medicines. Fact Sheet no 388. Geneva. Available at [http://www.who.int/mediacentre/facsheet/fs388/en/].

Xi L, Ruan, J and Huang Y (2012). Diversity and biosynthetic potential of culturable actinomycetes associated with marine sponges in the China seas. Int. J. Mol. Sci. 13: 5917-5932.

Zhao K, Penttinen P, Guan T, Xiao J, et al. (2011). The diversity and anti-microbial activity of endophytic actinomycetes isolated from medicinal plants in Panxi plateau, China. Curr. Microbiol. 62: 182-190.

Zhong X, Tian Y, Niu G and Tan H (2013). Assembly and feature of secondary metabolite biosynthetic gene clusters in Streptomyces ansochromogenes. Sci. China Life Sci. 56: 609-618. 